\title{
DISTRIBUTION OF PHLEBOTOMINE SANDFLIES (DIPTERA: PSYCHODIDAE) OF MEDICAL IMPORTANCE IN MATO GROSSO STATE, BRAZIL
}

Ana Lúcia Maria RIBEIRO(1), Nanci Akemi MISSAWA(2) \& Peter ZEILHOFER(3)

\begin{abstract}
SUMMARY
Intense environmental impacts, causing alterations of the natural habitats of fauna, including those of sandfly disease vectors are observed in Mato Grosso State, Central Brazil. Entomologic survey of phlebotomines was based on light trap and was carried out by entomological nucleus of the FUNASA and SES in the period between 1996 and 2001. Eighty eight species were identified, including the following sandflies with medical importance to leishmaniasis: Lutzomyia amazonensis, $L$. anduzei, $L$. antunesi, $L$. ayrozai, $L$. carrerai carrerai, L. complexa, $L$. cruzi, L. flaviscutellata, $L$. intermedia, $L$. longipalpis, $L$. migonei, $L$. paraensis, $L$. ubiquitalis, $L$. whitmani and $L$. yuilli yuilli. Most sandflies of medical importance occurred in the Amazon forest and savannah. $L$. longipalpis and L. cruzi had high densities in the savannah region. L. flaviscutellata is predominating in both the Amazon forest and the savannah region. L. whitmani and L. antunesi were sampled in the Amazon forest, savannah and marsh land.
\end{abstract}

KEYWORDS: Lutzomyia; Phlebotomine sandflies; Mato Grosso.

\section{INTRODUCTION}

Transmission of morbid agents by insects in metropolitan as well as in rural areas are frequently associated to precarious living conditions of human population and can be linked in rural zones to fishing and hunting activities, specific climatic, geomorphologic or soil conditions or deforestation of native vegetation ${ }^{5,12}$.

The phlebotomine sandflies are responsible for the transmission of leishmaniasis parasites. The life cycle starts when parasites are picked up by the sand fly during the blood meal where it evolves and multiplies inside the sandfly ${ }^{15}$.

Sandflies of the neotropics are usually grouped in one of three different genera: Brumptomyia (França \& Parrot, 1921), Warileya (Hertig, 1948) and Lutzomyia (França, 1924). Only the last one includes species of medical importance for the transmission of leishmaniasis.

Entomological investigations should include information about spatial distribution of the vectors and its relation to socio-economical and environmental factors, in order to develop predictive risk models, evaluate the main characteristics of transmission cycles, help in the delimitation of areas for focal control, monitoring of fluctuations of vector foci and planning insecticide application for vector control ${ }^{6,7}$.

Previous phlebotomines surveys in Mato Grosso had only covered selected municipalities ${ }^{6}$. RIBEIRO \& MISSAWA ${ }^{19}$ presented first results on spatial distribution of phlebotomines fauna in the main biomes of the Mato Grosso State and MISSAWA \& LIMA ${ }^{16}$ had verified the spatial distribution of visceral leishmaniasis vectors in the state. COSTA et al. ${ }^{7}$ and RODRIGUES et al. ${ }^{20}$ sampled some areas in the middle north and southern regions of the state, respectively. AZEVEDO et $a .^{2}$ have conducted captures in Peixoto de Azevedo, in the north of the state, RIBEIRO et al. ${ }^{18}$ in the influence area Manso hydropower plant and BIANCARDI \& CASTELLÓN ${ }^{3}$ in the municipality of Chapada dos Guimarães.

After surging suspects that the Lutzomyia cruzi (Mangabeira, 1938) is the vector of visceral leishmaniasis ${ }^{21}$, registries on autochthonous transmission of visceral leishmaniasis and observations of some foci of this disease in the state ${ }^{13,14}$, entomological surveillance begun to monitor spatial distribution of vector and disease occurrences in Mato Grosso,

In January of 1988, a large number of cutaneous leishmaniasis and the first cases of visceral leishmaniasis were registered in the city of Várzea Grande ${ }^{4}$. Due to increasing prevalence of the disease, responsible authorities recognized the necessity of a regular entomologicalepidemiological surveillance in the state, in accordance with the federal program for visceral leishmaniasis control, which pointed out the importance of entomologic studies for the disease control.

On this background, the present study systematizes all entomological survey data on leishmaniasis vectors acquired in Mato

(1) Hospital Universitário Júlio Muller, Faculdade de Ciências Médicas, Universidade Federal de Mato Grosso, MT, Brasil.

(2) Secretaria Estadual de Saúde de Mato Grosso, MT, Brasil.

(3) Departamento de Geografia, Universidade Federal de Mato Grosso, MT, Brasil.

Correspondence to: Dra. Ana Lúcia Maria Ribeiro, R 20, nº. 237, C 04, Boa Esperança, 78068-380 Cuiabá, MT, Brasil. Phone: +55.65.3664-2615. E-mail: anadarlingi@yahoo.com.br 
Grosso during the last years in a spatial-temporal database, in order to analyze geographical distribution of phlebotomine sandflies species inside main biomes and relate them to land use patterns.

\section{MATERIAL AND METHODS}

The entomological survey of phlebotomine sandflies was conducted from 1996 to 2001 and included 41 of the 139 municipalities of the state of Mato Grosso (Fig. 1): Alto Araguaia, Araguaiana, Arenápolis, Aripuanã, Barão de Melgaço, Barra do Garças, Cáceres, Campo Verde, Chapada dos Guimarães, Cláudia, Comodoro, Diamantino, Dom Aquino, Feliz Natal, Gaúcha do Norte, Guarantã do Norte, Juína, Marcelândia, Matupá, Nobres, Nortelândia, Nossa Senhora do Livramento, Nova Brasilândia, Nova Lacerda, Nova Guarita, Nova Mutum, Nova Ubiratã, Paranatinga, Poconé, Pontal do Araguaia, Pontes e Lacerda, Poxoréu, Querência, Rosário Oeste, São Félix do Araguaia, Santo Antônio do Leverger, Sorriso, Tapurah, Terra Nova do Norte, Várzea Grande and Vila Bela da Santíssima Trindade.

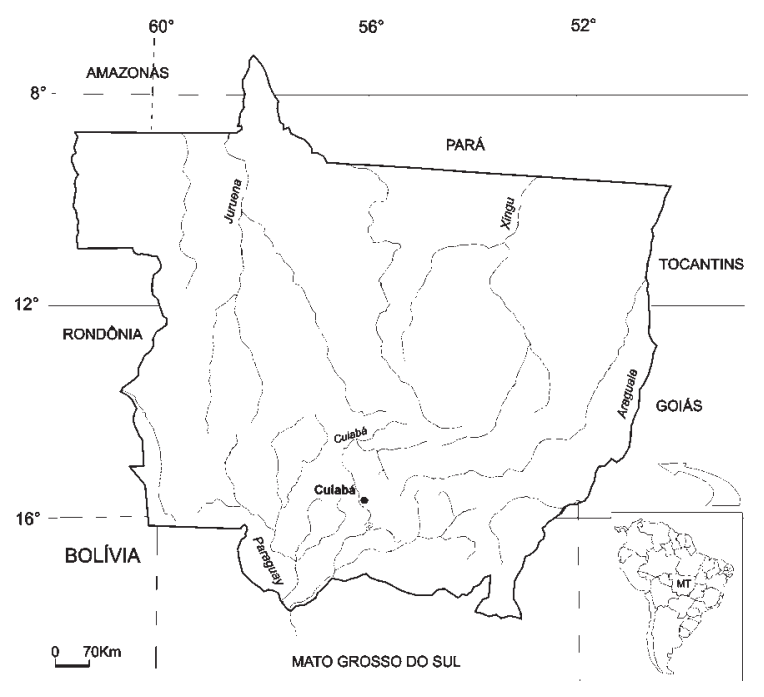

Fig. 1 - Study area: Mato Grosso State, Brazil.

Sampling campaigns were realized by members of the Entomology Laboratory of the Fundação Nacional de Saúde (FUNASA) and Secretaria Estadual de Saúde of Mato Grosso (SES) using light trap captures (CDC light trap). In each of the 106 random campaigns, between nine and 15 CDC traps were proportionally distributed in intra (indoor), peri (pigsty and chicken houses) and extradomiciliary (forest border) ecotopes. Sampling was simultaneously initiated at dusk with duration of 12 hours.

Collected specimens were stored in $70 \%$ alcohol, cleared and identified to species according to YOUNG \& DUNCAN ${ }^{23}$.

For each trap, insect specific Trap Indexes-TI (number of individuals of each species per trap per night) were calculated. TI values of trap and species were then averaged for each municipality. If more than one campaign was done per municipality, the TIs of each collecting were averaged. Specimens are available for consultation at the
Entomology Laboratory of the SES.

The map of Mato Grosso districts in a 1:1,500,000 scale was made available by Secretaria de Planejamento (SEPLAN) ${ }^{22}$ in digital form. The thematic map of Mato Grosso vegetation types in a 1:1,500,000 scale was obtained from Instituto Brasileiro de Geografia e Estatística $(\mathrm{IBGE})^{8}$. A layer representing the zones of intense land use in Mato Grosso was digitalized through visual interpretation of a MODIS Global Land Cover Layer (1 km resolution) from 2001. Both thematic maps were georeferenced to a polyconic projection according to district map. Spatial data processing was realized using standard GIS functions available through the ArcView 3.2 software (ESRI).

\section{RESULTS}

The entomologic survey resulted in the capture of individuals belonging to 88 phlebotomine sandflies species. Figure 2 represents averaged TI for four of the medically most important sandflies species in Mato Grosso: Lutzomyia cruzi and L. longipalpis (Lutz \& Neiva, 1912), the main vectors for the transmission of visceral leishmaniasis, as well as L. flaviscutellata (Mangabeira, 1942a) and L. whitmani (Antunes \& Coutinho, 1939), the main species responsible for the transmission of cutaneous leishmaniasis ${ }^{15}$. Point signatures are scaled according to TI values.

Figures $3 \mathrm{a}$ and $\mathrm{b}$ represent averaged TIs of 11 additional species with importance for leishmaniasis transmission: L. amazonensis (Root, 1934), L. anduzei (Roseboom, 1942) according to MARCONDES ${ }^{15}$; L. antunesi (Coutinho, 1939) according to CIPA ${ }^{6}$, L. ayrozai (Barretto $\&$ Coutinho, 1940) according to MARCONDES ${ }^{15}$ and GALATI $^{11} ; L$. carrerai carrerai (Barretto, 1966), L. complexa (Mangabeira, 1941c), L. intermedia (Lutz \& Neiva, 1912), according to MARCONDES ${ }^{15} ; L$. migonei (França, 1920), L. paraensis (Costa Lima, 1941), L. ubiquitalis (Mangabeira, 1942a) according to RANGEL \& LAINSON ${ }^{17}$ and $L$. yuilli yuilli (Young \& Porter, 1972), according to MARCONDES ${ }^{15}$. The circles in the Figure 3 are scaled according to accumulated average TI of represented species, when percentages of species are represented by circle sectors.

Among 15 species with medical importance, only four species $L$. antunesi, $L$. cruzi, L. longipalpis and $L$. whitmani were encountered in all types of vegetation of Mato Grosso State. L. paraensis and $L$. ubiquitalis were only found in municipalities of the savannah region and specimens of L. ayrozai were only captured in the Amazon forest. The other eight species were found in two types of vegetation, the Amazon forest and savannah.

L. cruzi, even sampled in one of the Amazon forest municipalities, seems to have its predominant area in the central and southern parts of the state, in the savannah and marsh land region (Fig. 2a). L. longipalpis have high densities in the savannah region and occurs also in the marsh land (Fig. 2b).

L. flaviscutellata, mentioned as a relevant species for leishmaniasis transmission was found in both the Amazon forest and the savannah region (Fig. 2c), but with much lower average densities (maximum value of 3.7 in the Amazon forest municipality of Aripuanã) than $L$. cruzi or L. whitmani. In our survey, L. whitmani showed higher TIs in 

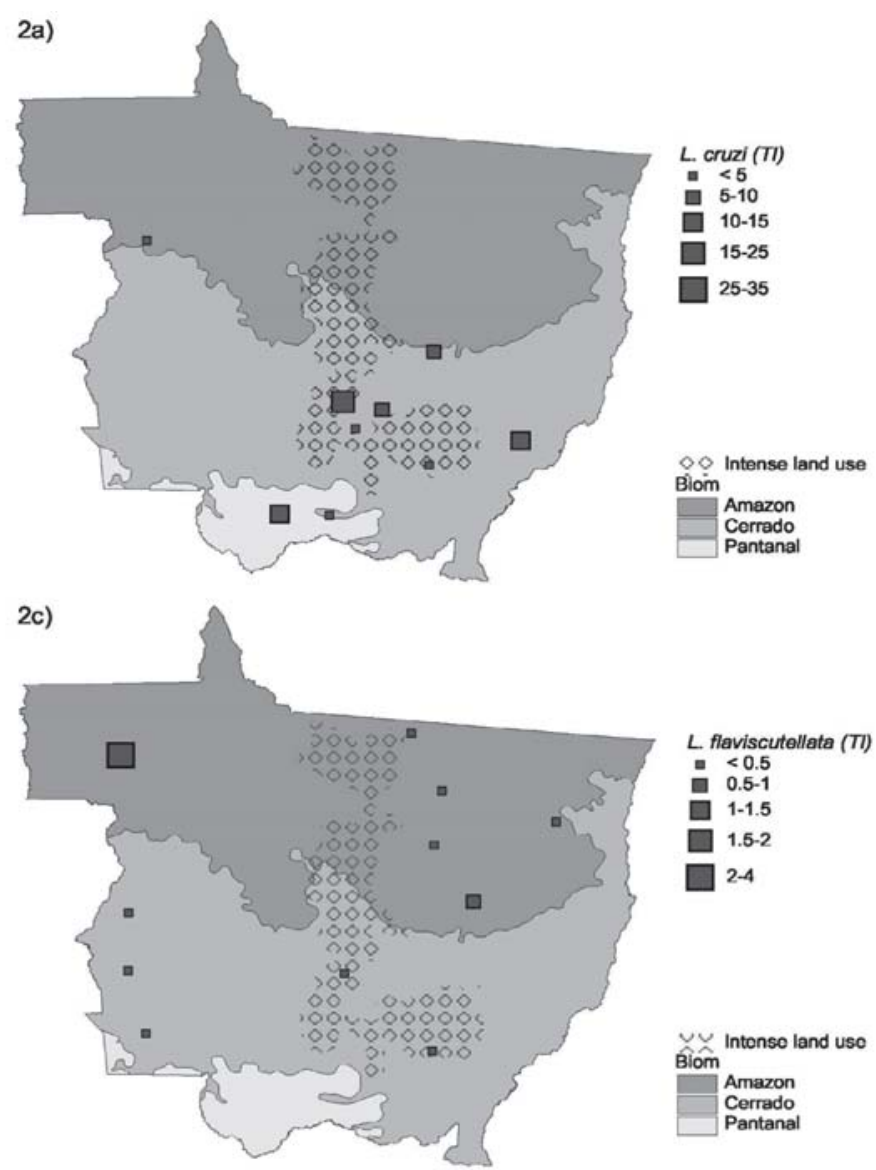
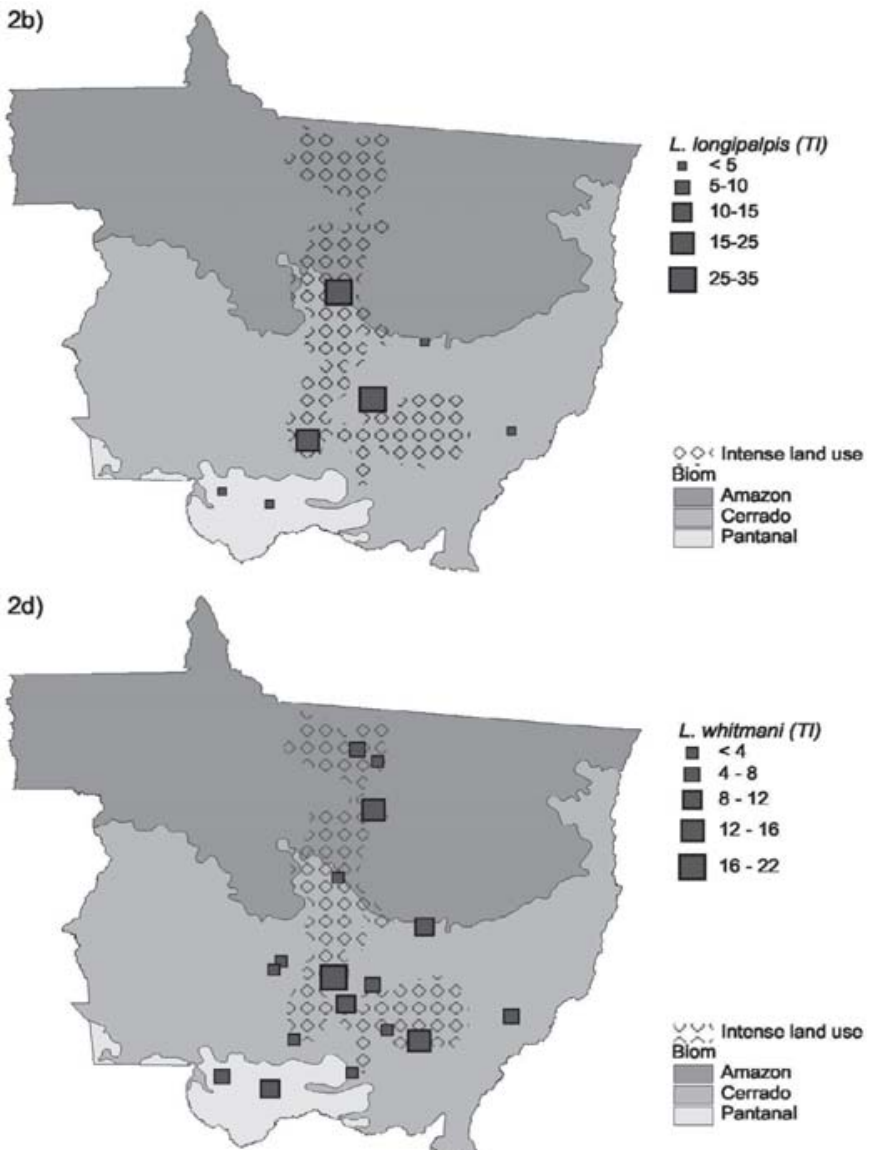

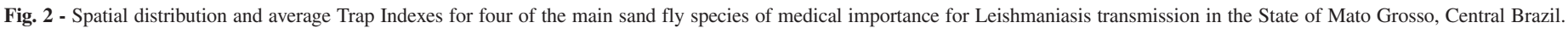

the zone of agricultural expansion (Fig. 2d) in the savannah and Amazon forest vegetation of the middle north and south-eastern regions of the state (Rosário Oeste, Cláudia, Chapada dos Guimarães and Poxoréu) and in two most densely occupied municipalities in the marsh land (Poconé and Cáceres).

L. antunesi was common in all types of vegetation of Mato Grosso (Fig. 3a), with elevated TI means of up to 13.8. L. migonei (Fig. 3b) was found in five municipalities in the northern territories of Mato Grosso, but TIs did never reach 4. L. ayrozai and L. ubiquitalis, both captured only in a unique municipality had an average TI of 0.67 and 0.12 respectively and are therefore not visible as sectors in Fig. 3a and b respectively.

L. amazonensis, L. ayrozai, L. carrerai carrerai, L. complexa, $L$. paraensis, L. yuilli yuilli and other species of medical importance to leishmaniasis (Fig. 3a and b) were found to have a limited geographical distribution or low TI values.

\section{DISCUSSION}

Our results indicate that phlebotomine sandflies fauna in Mato Grosso is richer than reported until now. Computer-aided identification of phlebotomine sandflies of America (CIPA) ${ }^{6}$ had quoted 52 species in the state, among them, as in our study L. longipalpis, L. migonei, $L$. anduzei, L. antunesi (Coutinho, 1939), L. flaviscutellata, L. umbratilis (Ward \& Fraiha, 1977), L. whitmani and L. yuilli yuilli. The most recent work of AGUIAR \& MEDEIROS ${ }^{1}$ stated 73 species for Mato Grosso. AZEVEDO et al. ${ }^{2}$, studied phlebotomine sandfly fauna in Peixoto de Azevedo, in the north of the state, a region which is mainly formed by evergreen forests, transitional forests and savannah and identified 26 species, including L. spathotrichia (Martins, Falcão \& Silva, 1963), L. runoides (Fairchild \& Hertig, 1953), L. llanosmartinsi (Fraiha \& Ward, 1980), L. whitmani, L. antunesi, L. carrerai carrerai, L. complexa, L. lainsoni (Fraiha \& Ward, 1974).

According to studies of MARCONDES ${ }^{15}$, GALATI ${ }^{11}$, YOUNG \& DUNCAN $^{23}$ and RANGEL \& LAINSON ${ }^{17}, 15$ species from the 88 captured species have medical importance for leishmaniasis transmission. RIBEIRO et al. ${ }^{18}$ surveyed phlebotomine sandflies fauna around the reservoir of the Multiple Use of Manso plant (APM Manso), which includes the municipal districts of Chapada dos Guimarães, Nobres, Rosário Oeste and Nova Brasilândia located in the savannah region. Six of the 32 species captured are of medical interest: $L$. antunesi, L. cruzi, L. longipalpis, L. flaviscutellata, L. whitmani and L. intermedia. 

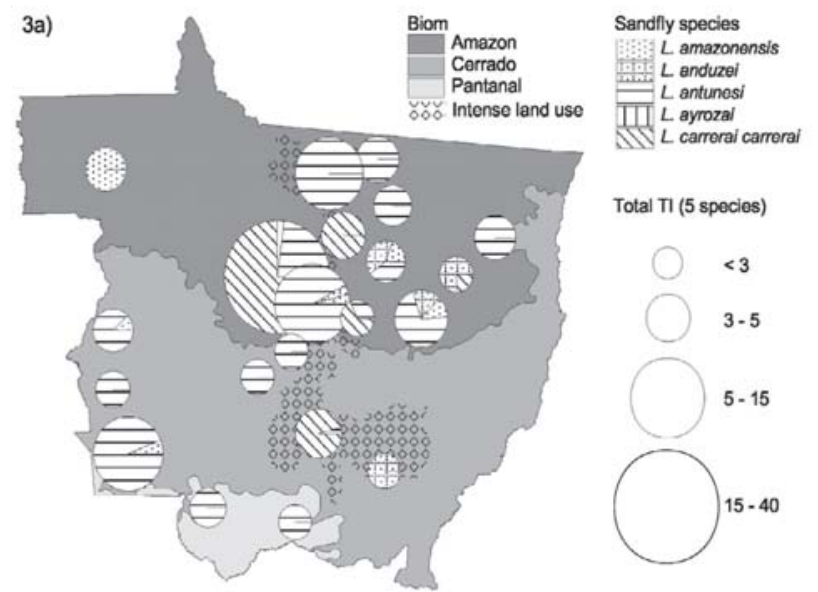

Total TI (5 species)
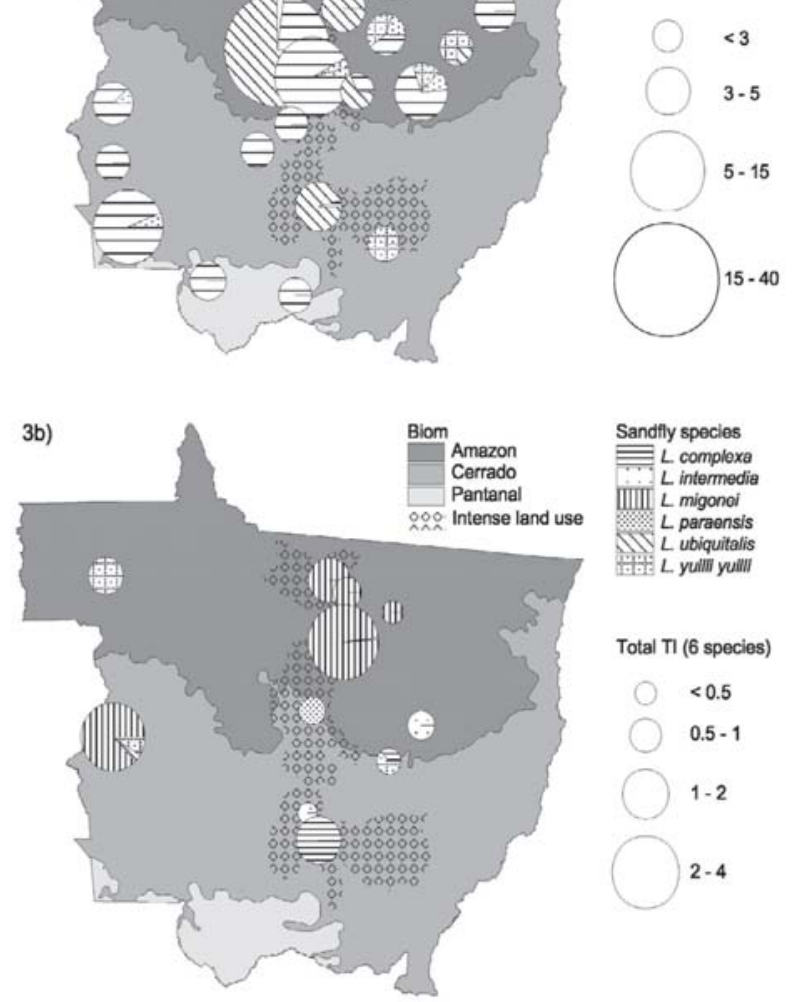

Total TI (6 species)

$<0.5$

$0.5-1$

$1-2$

$2-4$
Fig. 3 - Spatial distribution and average Trap Indexes for eleven sandflies species of medical interest for Leishmaniasis transmission in the State of Mato Grosso, Central Brazil.

Comparing our captures with mentioned previous studies, the following 15 species were first collected in Mato Grosso State: $L$. dasymera (Fairchild \& Hertig, 1961), L. dreisbachi (Causey \& Damasceno, 1945), L. goiana Martins, Falcão \& Silva, 1962, L. servulolimai (Damasceno \& Causey, 1945), L. termitophila Martins, Falcão \& Silva, 1962, L. amazonensis (Root, 1934), L. inflata (Floch \& Abonnenc, 1944), L. hirsuta nicaraguensis (Fairchild \& Hertig, 1961), L. ruii Arias \& Young, 1982, L. baculus Martins, Falcão \& Silva, 1962, L. cruciata (Coquillett, 1907), L. longispina (Mangabeira, 1942d), L. brisolai Le Pont \& Desjeux 1987, L. intermedia (Lutz \& Neiva, 1912), L. dubitans (Sherlock, 1962).

Our study confirmed the findings of CIPA $^{6}$ who recently reported L. cruzi in urbanized environments, such as in the districts of Poconé, Chapada dos Guimarães and Poxoréu. COSTA et al. ${ }^{7}$ identified L. cruzi in more densely occupied municipalities of Poconé, Chapada dos Guimarães and Poxoréu. Our exploratory analysis, however, does not indicate higher TIs of $L$. cruzi in municipalities with more intense land use. In recent work, MISSAWA \& LIMA $^{16}$ observed the occurrence of this species in 22 municipalities of the state.
COSTA et al. ${ }^{7}$ pointed out a significant occurrence of $L$. longipalpis in the densely populated districts of Várzea Grande and in regions of intense or beginning agricultural expansion such as Sorriso, Chapada dos Guimarães and Nova Ubiratã, respectively. In our research, all campaigns which resulted in elevated TI $(>20)$ were conducted in municipalities with intense land occupation (Várzea Grande, Nova Brasilândia and Sorriso), following the north-south axis of the state growth along the BR 163 highway, indicating ongoing domiciliation of this species. MISSAWA \& LIMA ${ }^{16}$ observed this species in 23 municipalities of the state.

In our campaigns, no specimen of L. flaviscutellata was catalogued in the metropolitan area of Várzea Grande. Recent, not published captures in the context of epidemiologic surveys of canine leishmaniasis, however, encountered L. flaviscutellata in the urban areas of Cuiabá. BIANCARDI \& CASTELLÓN³ captured specimens in rural areas of Chapada dos Guimarães.

The capture of L. whitmani reinforces the results obtained by RODRIGUES et al..$^{20}$, who mentioned the domiciliation of this vector of cutaneous leishmaniasis in rural settlements of the Brazilian government agrarian reform program (Reforma agrária), in the municipalities of Chapada dos Guimarães and Nova Ubiratã. Recent, not published captures diagnosed L. whitmani in the urban areas of Cuiabá and Várzea Grande as well.

As shown in Fig. 3, L. antunesi does not seem to follow regions of more intense land occupation. AZEVEDO et al. ${ }^{2}$ sampled this species in northern Amazon forest municipalities, but it was also catalogued in the metropolitan area of Cuiabá (FUNASA, not published).

Our study on the spatial distribution of phlebotomine sandflies species in Mato Grosso, allows the following conclusions:

Geographical distribution of phlebotomine sandflies vectors in the state is complex, and no common patterns for the most frequent species with medical importance for leishmaniasis transmission could yet be shown. Most species, however, occur in the savannah and Amazon forest, considering that these two geoecological units occupy more than $90 \%$ of the territory of the state.

At least two of the most common vectors of visceral and cutaneous leishmaniasis, L. longipalpis and L. whitmani, respectively, were found to have highest TIs values in urbanized areas and regions of intense agricultural expansion, indicating its ongoing domiciliation.

The application of exploratory GIS techniques was found to be useful to subsidize entomological surveillance and the identification of risk areas, looking forward to improve public health services and control of leishmaniasis in Mato Grosso.

\section{RESUMO}

\section{Distribuição de flebotomíneos (Diptera: Psychodidae) de importância médica no Estado de Mato Grosso, Brasil}

O estado de Mato Grosso, Brasil vem sendo grandemente impactado, o que provoca uma alteração no habitat natural da fauna, 
incluindo-se os vetores das leishmanioses. Foram analisados dados de levantamentos entomológicos realizados pela FUNASA e SES no período de 1996 a 2001. Foram capturados indivíduos pertencentes a 88 espécies, sendo as de importância para a transmissão das leishmanioses: Lutzomyia amazonensis, L. anduzei, L. ayrozai, $L$. carrerai carrerai, L. complexa, L. cruzi, L. flaviscutellata, $L$. intermedia, L. longipalpis, L. migonei, L. paraensis, L. ubiquitalis, $L$. whitmani e L. yuilli yuilli, as quais foram plotadas no mapa do Estado. A maioria das espécies de importância médica compartilha a vegetação de floresta Amazônica e cerrado. L. longipalpis e L. cruzi possuem altas densidades na região de cerrado. L. flaviscutellata predomina na floresta Amazônica e no cerrado. L. whitmani e L. antunesi foram capturadas na floresta Amazônica, cerrado e pantanal.

\section{ACKNOWLEDGMENTS}

We gratefully thank technicians of the Entomology Laboratory (FUNASA and SES), who intensely assisted our field and laboratory work, essential for the development of this research.

\section{REFERENCES}

1. AGUIAR, G.M. \& MEDEIROS, W.M. - Distribuição regional e hábitats das espécies de flebotomíneos do Brasil. In: RANGEL, E.F. \& LAINSON, R., ed. Flebotomíneos do Brasil. Rio de Janeiro, Editora Fiocruz, 2003. p. 207-255.

2. AZEVEDO, A.C.R.; SOUZA, N.A.; MENEZES, C.R.V. et al. - Ecology of sand flies (Diptera: Psychodidae: Phlebotominae) in the North of the State of Mato Grosso, Brazil. Mem. Inst. Oswaldo Cruz, 97: 459-464, 2002.

3. BIANCARDI, C.A.M \& CASTELLÓN, E.G. - Flebotomíneos (Diptera: Psychodidae) no Estado de Mato Grosso, município de Chapada dos Guimarães, Brasil. Acta amaz. (Manaus), 30: 115-128, 2000.

4. CAMIÁ, R.P.; RINALDI, J.; FONTE, C.J.F. \& HUEB, M. - Foco de leishmaniose visceral em Mato Grosso. In: REUNIÃO ANUAL DE PESQUISA APLICADA EM DOENÇA DE CHAGAS, 15., e REUNIÃO DE PESQUISA APLICADA EM LEISHMANIOSES, 3., Uberaba, 1999. Rev. Soc. bras. Med. trop., 32(suppl. 2): 127-128, 1999.

5. CASTRO, E.A.; LUZ, E.; TELLES, F.Q. et al. - Eco-epidemiological survey of Leishmania (Viannia) braziliensis American cutaneous and mucocutaneous leishmaniasis in Ribeira Valley River, Paraná State, Brazil. Acta trop., 93: 141-149, 2005.

6. COMPUTER-aided Identification of Phlebotomine Sandflies of America - Phlebotomine species of Mato Grosso, 1999. http://www.cipa.snv.jussieu.fr (accessed in 01/Feb/ 2005).

7. COSTA, L.B.; BERTÚLIO, M.A.; RODRIGUES, H. et al. - Ocorrência de flebotomíneos vetores da leishmaniose visceral nos municípios do Estado de Mato Grosso. Rev. Abrasco, 8 (suppl. 2): 639, 2003.

8. FUNDAÇÃO IBGE - Biomas do Brasil. Escala 1:1.500.000, 2004. http:// www.ibge.gov.br (accessed in Apr/2004).

9. FUNDAÇÃO NACIONAL DE SAÚDE - Atualização da metodologia e estratégias de controle da leishmaniose visceral no Brasil. (Oficina de Trabalho). Fortaleza, Ministério da Saúde, 2001.
10. FUNDAÇÃO NACIONAL DE SAÚDE - Manual de vigilância e controle da leishmaniose visceral. Brasília. Ministério da Saúde, 2003.

11. GALATI, E.A.B. - Phlebotominae (Diptera, Psychodidae). Biologia, classificação, morfologia, terminologia e identificação de adultos. São Paulo, Curso de Entomologia Médica, 2000.

12. GEBRE-MICHAEL, T.; MALONE, J.B.; BALKEW, M. et al. - Mapping the potential distribution of Phlebotomus martini and P. orientalis (Diptera: Psychodidae), vectors of kala-azar in East Africa by use of geographic information systems. Acta trop., 90: 73-86, 2004.

13. HUEB, M.; ASSIS, S.B.; GUIMARÃES, E.E.D.; ROSA, D.L. \& FONTES, C.J.F. Ocorrência de transmissão autóctone de leishmaniose visceral em Mato Grosso. Rev. Soc. bras. Med. trop., 29: 281-282, 1996.

14. HUEB, M.; CAMIÁ, R.P.; RIBEIRO, L.C. \& FONTES, C.J.F. - Calazar em Mato Grosso: foco recente em área periurbana. Rev. Soc. bras. Med. trop., 33 (suppl. 1): 324, 2000.

15. MARCONDES, C.B. - Entomologia médica e veterinária. São Paulo, Atheneu, 2001.

16. MISSAWA, N.A. \& LIMA, G.B.M. - Distribuição espacial de Lutzomyia longipalpis (Lutz \& Neiva, 1912) e Lutzomyia cruzi (Mangabeira, 1938) no estado de Mato Grosso. Rev. Soc. bras. Med. trop., 39: 337-340, 2006.

17. RANGEL, E.F. \& LAINSON, R. - Ecologia das leishmanioses. In: RANGEL, E.F. \& LAINSON, R. Flebotomíneos do Brasil. Rio de Janeiro, Fiocruz, 2003. p. 291-309.

18. RIBEIRO, A.LM.; OLIVEIRA, R.C.; MIYAZAKI, R.D. \& PIGNAT, W.A. - Inventário dos vetores da leishmaniose (Diptera: Psychodidae: Phlebotominae) em área de aproveitamento múltiplo de Manso, Chapada dos Guimarães, Nobres, Rosário Oeste e Nova Brasilândia - Mato Grosso/Brasil (Dados preliminares). In: CONGRESSO DA SOCIEDADE BRASILEIRA DE MEDICINA TROPICAL, 38, Foz do Iguaçu, 2002. Rev. Soc. bras. Med. trop., 35 (suppl. 1): 313, 2002.

19. RIBEIRO, A.L.M \& MISSAWA, N.A. - Spatial distribution of phlebotomine species in the State of Mato Grosso, Brazil, in the period of 1996 to 2001. Entomol. Vect., 9(suppl. 1): 33-34, 2002.

20. RODRIGUES, H.; MISSAWA, N.A.; COSTA, L.B. et al. - A interferência humana como fator de agravamento ambiental e a domiciliação dos vetores da leishmaniose tegumentar americana no Estado de Mato Grosso, no período de 2001 e 2002. Rev. Abrasco, 8(suppl. 1): 414, 2003.

21. SANTOS, S.O.; ARIAS, J.; RIBEIRO, A.A. et al. - Incrimination of Lutzomyia cruzi as a vector of American visceral leishmaniasis. Med. vet. Entomol., 12: 315-317, 1998.

22. SECRETARIA DE PLANEJAMENTO. SEPLAN - Zoneamento sócio-econômicoecológico do Estado de Mato Grosso-ZSEE. Escala 1:1.500.000, 2004.

23. YOUNG, D.G. \& DUNCAN, M.A. - Guide to the identification and geographic distribution of Lutzomyia sand flies in Mexico, the West Indies, Central and South America (Diptera: Psychodidae). Florida, Associate Publishers American Entomological Institute, 1994.

Received: 22 December 2006

Accepted: 9 May 2007 